\title{
A STATISTICAL STUDY OF FEDERAL CRIMINAL PROSECUTIONS
}

\author{
EDWARd Rubin*
}

The increasing demand for federal control of crime and the response accorded it during the last session of Congress suggests the need for an inquiry into the amount and nature of criminal law business handled in recent years by the federal courts of first instance. Only one source of information is available. ${ }^{\perp}$ Each year the Attorney General of the United States publishes statistics in his Annual Report indicating the number of criminal prosecutions pending, commenced, and terminated in the federal district courts. By collating certain of these statistics in a series of tables which follow in the main the Attorney General's classification, the results of the criminal law enforcement activities of the federal government during a given period may be shown.

\section{Nature of the Statistical Material Used}

With the exception of Table I, the tables presented herein will contain statistics relating to the criminal law business of the federal district courts for the fiscal years I922 to I933 inclusive. In I922 so extensive a change was made in the classification used in the Annual Reports of the Attorney General of the United States that the data available for the years prior thereto are not sufficiently comparable to permit tabulation with those for the more recent period, except in Table $x$ where the classification used by the Attorney General permits compilation for at least a thirty-year period. However, some comparisons with the years antedating r922 are possible, and where these seem significant, the available data will be presented.

Except where otherwise indicated, the statistics tabulated are confined to prosecutions commenced in the district courts of the United States. The unit of criminal prosecutions commenced in each fiscal year has been regarded as preferable for the purposes of this survey to one based on the number of cases terminated because the former unit gives a better indication for a given year of the federal offenses committed and of the police activity of the federal government in that year. If the unit were cases terminated, the data for any given year would, of course, include cases pending for a number of years and representing by-gone offenses. ${ }^{2}$

- A.B., I933, University of California at Los Angeles. Now a member of the second year class in the Duke University School of Law.

${ }^{1}$ However, a valuable detailed study of cases arising in the Connecticut federal district court during the three fiscal years ending June 30, 1930, may be found in Progress Report on the Study of the Federal Courts (Nat. Comm. on Law Observance and Enforecment, No. 7, May 28, 1931).

2 Thus, in the fiscal year $1925,17,895$ cases involving violations of selective service laws were ter- 
It should be understood that the unit of compilation-criminal prosecutions commenced in each fiscal year-is by no means a perfect measure of federal law enforcement activity and, standing alone, throws no light on the outcome of the prosecutions instituted. To indicate the results of criminal prosecutions commenced, data as to certain offenses, comparing convictions and terminations in the district courts, will be set forth in Table 9. That the federal court statistics are not free from defects, no matter what unit one may choose, is tersely pointed out by Morris Ploscowe, writing in the Report on Criminal Statistics of the National Commission on Law Observance and Enforcement. "The unit taken for compilation," say Ploscowe, "is the individual case. This is a good basis for measuring the activity of the courts. However, it gives us no exact idea of the number of violations of the law which were disposed of by the court, since a single case may be concerned with more than one offense."

"Nor does the use of this unit provide exact information as to the number of delinquents before the court, or of the number convicted or acquitted," he continues. "A defendant may be convicted twice or three times during the year. Each conviction is entered into the statistics. Any case may have one or roo defendants. At the present time, where a number of persons are indicted and one or more convicted, the case is entered just once as one conviction. If roo defendants are indicted in one case and only one conviction is obtained, one conviction is entered and nothing is shown about the 99 failures to convict. It may be seen then that proper account is not taken of the result of action against individual defendants. The statistics present, therefore, an insufficient and misleading picture of what happens in criminal cases."

In the tables which follow, the classification and column headings found in the Annual Reports of the Attorney General, I922 through I933, will be used to a great extent. 5 Such departures as are made from this classification will be noted. Although far superior to the classification used prior to I922, the Attorney General's current classification has also been subjected to criticism. The main headings, it is

minated by noll. pros. Only 6 criminal prosecutions were commenced in that year for selective service violations. REP. ATT'y GEN. (I925) 8I.

${ }^{3}$ Ploscowe, A Critique of Federal Statistics, Report on Criminal Statisncs (Nat. Comm. on Law Observance and Enforcement, No. 3, April r, I931) I78, r79.

"Thus, to take an extreme example, 8,638 violations of the Harrison Anti-Narcotic Act accrued during the fiscal year 1923 against unregistered persons and 33,268 violations against registered persons. See Rep. Comm. InT. Rev. (1923) 301. Table 4, infra, indicates that only 4,393 prosecutions were commenced during that year for violations of this Act.

The classification adopted by the Attorney General in 1922 contained the following headings and sub-headings: I Customs. II Internal revenue. III Postal. IV Regulation of commerce: (a) Anti-trust; (b) Regulation of public utilities, (I) Interstate Commerce Commission, (2) Hours of service act, (3) 28hour law, (4) Safety appliance act, (5) Thefts, (6) Other cases; (c) Food and fuel regulations, (I) Food and drugs act, (2) Meat inspection act, (3) Other cases; (d) Miscellaneous forms of regulation, (I) Quarantine acts, (2) Game-bird acts, (3) Insecticide and fungicide acts, (4) Virus acts, (5) Shipping acts, (6) Other cases, V Public Health and safety: (a) National prohibition act; (b) Other liquor traffic cases; (c) Anti-narcotic acts; (d) White slave act; (c) Peonage; (f) Other cases. VI Banking and finance: (a) National banking laws; (b) Federal reserve act; (c) Federal farm loan act; (d) War finance corporation (replaced by "Bankruptcy act" in 1927); (e) Other cases. VII Liability and insurance: (a) War risk insurance; (b) Federal employees compensation acts; (c) Pension acts; (d) Federal retirement act; (c) Other cases. VIII Foreign Relations: (a) Immigration; (b) Naturalization; (c) Trading with enemy; 
said, do not distinguish crimes of different categories. The sub-categories lump "heterogeneous infractions" together..$^{\text {" }}$

Forewarned is forearmed. Despite the difficulties involved in the use of federal criminal statistics, it is believed that the following tables will present a fair indication of the criminal law business of the federal district courts and its development in the post-war period, and will permit some interpretation with respect to such trends as may be noted therein.

\section{Criminal Prosecutions in the United States District Courts ${ }^{0}$}

\section{General.}

Table $I$ indicates the number of criminal prosecutions commenced during each fiscal year in the United States for the thirty-three year period terminating on June 30, 1933. A word as to its scope: In order to present a picture of the trend of federal criminal law activities, it has been considered advisable to deduct from the column designated "Total" all prohibition and war cases and those cases arising in the District of Columbia and the Indian Territory listed in the Reports of the Attorney General under the heading "not specially classified." The cases thus segregated do not represent the regular current of federal law enforcement activities, the course of which can best be traced by reference to the two columns at the right of this table. The column designated "Prohibition" concerns itself with prosecutions for violations of the National Prohibition Act of October 28, I9r9 (the Volstead Act), listed in the Reports under the same heading. The column designated "War Cases" includes prosecutions commenced during the fiscal years I922-I933 for criminal matters connected with war trade and industries, alien property, trading with the enemy, and selective service. Prior to 1922 the war cases consist of violations of the Selective Service and the Espionage Acts. The District of Columbia column in Table 4 consists of such cases arising in the Supreme Court and the Police Court of the District of Columbia as are not specially classified in the yearly Reports. From the volume of such cases in the District, it is evident that they comprise chiefly offenses similar to those tried in state courts of general jurisdiction and do not therefore

(d) Alien property; (c) War trade and industries; (f) Admiralty. IX Public lands: (a) Public lands and reservations; (b) Indian lands; (c) Condemnation proceedings; (d) Reclamation and water rights; (c) Other cases. X Not specially classificd: (a) Selective-service; (b) Indian matters; (c) Other cascs.

The following classification, taken from the $192 \mathrm{I}$ Report, is basically that used from 1908 to $192 \mathrm{I}$. There were some additions and deletions in the period. No sub-headings were employed. ( 1 ) Customs. (2) Internal revenue. (3) Post office. (4) Banking acts. (5) Land laws and timber trespass. (6) White slave. (7) Food and drugs act. (8) Sherman anti-trust law. (9) Interstate commerce laws. (Io) Counterfeiting laws. (II) Selective draft. (I2) Espionage act. (13) National prohibition act. (14) Unclassified.

5a See Ploscowe, op. cit. supra note 3, I75. In indicating the scope of the classifications used herein, no effort has been made to give an exhaustive enumeration of the federal statutes containing penal provisions. Only a small portion of these are collected in the United States Criminal Code (Unitcd States Code, Title I8). A convenient reference to penal provisions not included in that title is the 22-page table in 18 U. S. C. A. 407 et seq. (I927).

${ }^{6}$ For the years prior to the fiscal year ending 1912, the figures indicate the criminal prosecutions commenced in the Circuit as wcll as the District Courts. 
belong in a compilation of distinctively federal violations. The same may be said of the unclassified cases arising in the Indian Territory from rgor to $1907 .^{7}$

\begin{tabular}{|c|c|c|c|c|c|c|}
\hline \multirow[b]{2}{*}{ Year } & \multirow[b]{2}{*}{ Total } & \multicolumn{4}{|c|}{$\begin{array}{l}\text { Dist. of Columbia } \\
\text { Cases Not Specially }\end{array}$} & \multirow{2}{*}{$\begin{array}{l}\text { Net Cases } \\
\text { per roo,ooo } \\
\text { Population }\end{array}$} \\
\hline & & Prohibition & War Cases & Classified & Net & \\
\hline$\ldots \ldots$ & 82,675 & 57,553 & 2 & 5,97 It & I9, I 49 & 15.2 \\
\hline $932 \ldots \ldots \ldots$ & $92, \mathrm{I} 74$ & 65,960 & o & 5,772 & 20,442 & 16.4 \\
\hline rg3r......... & 83,747 & 57,405 & 0 & 5,576 & 20,766 & 16.7 \\
\hline I930......... & 87,305 & 56,992 & 2 & 7,957 & 22,354 & I8.x \\
\hline rg29......... & $86,34^{8}$ & $5^{6,786}$ & 0 & $x x, 544$ & 18,018 & I4.8 \\
\hline r928. & 83,372 & 55,729 & 0 & I0,706 & 16,937 & I4.I \\
\hline I927. . & $64,6 I_{4}$ & 40,709 & I & 9,694 & 14,210 & 12.0 \\
\hline rg26. . & $68,5^{82}$ & 44,492 & I & 8,682 & 15,407 & 13.2 \\
\hline $1925 \ldots \ldots \ldots$ & 76,136 & $5^{0,743}$ & 9 & 7,157 & 18,227 & 15.9 \\
\hline x $924 \ldots . . . \ldots$ & 70,168 & 45,878 & I & 8,935 & 15,354 & 13.6 \\
\hline $9923 \ldots \ldots \ldots$ & $7 \mathrm{r}, 077$ & $49,02 I$ & I7 & 7,674 & 14,365 & 12.9 \\
\hline $922 \ldots \ldots \ldots$ & 60,722 & 34,984 & 3,302 & 8,149 & I 4,287 & 13.0 \\
\hline $1921 \ldots \ldots \ldots$ & 54,487 & 29,114 & 1,337 & 6,943 & I7,093 & I6.6 \\
\hline rg20.................. & $55,5^{87}$ & 7,291 & $x 9,830$ & 6,922 & $2 I, 544$ & 20.2 \\
\hline IgIg. & 47,443 & & 16,230 & 8,297 & 22,916 & $2 \mathrm{r} .8$ \\
\hline IgI8. & 35,096 & & 12,797 & $6,44^{6}$ & $\mathrm{I}_{5}, 853$ & I5.3 \\
\hline 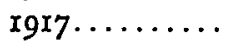 & 19,628 & & & 6,650 & $\mathrm{I} 2,97^{8}$ & 12.7 \\
\hline Igr6.......... & 20,243 & & & 6,945 & 13,298 & 13.2 \\
\hline rg15.......... & 19,868 & & & 6,999 & 12,869 & 12.9 \\
\hline $1914 \ldots \ldots \ldots$ & I8,399 & & & 6,965 & II, 434 & II.7 \\
\hline I9I3......... & r6,753 & & & 5,262 & II, $49 r$ & I 1.9 \\
\hline IgI2.......... & I5,953 & & & 5,243 & 10,710 & II. 3 \\
\hline IgII.......... & 15,057 & & & 4,946 & IO,YII & ro.8 \\
\hline rgro........... & 14,864 & Indian Terri- & & 4,899 & 9,965 & ro.8 \\
\hline rgog........... & $\mathrm{r}_{4,505}$ & tory Cases & & 4,962 & 9,543 & 10.5 \\
\hline 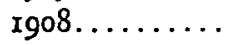 & 13,345 & & & 4,706 & 8,639 & $9 \cdot 7$ \\
\hline rg07........ & 18,332 & 5,3 II & & 4,782 & 8,239 & 9.4 \\
\hline rgo6.......... & I7,435 & 4,236 & & 4,682 & 8,517 & 9.9 \\
\hline 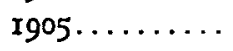 & 18,900 & 4,622 & & 4,742 & $9,53^{6}$ & II. 3 \\
\hline 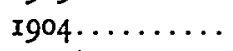 & 18,488 & $4,1 \times 9$ & & 4,242 & 10,127 & $\mathrm{r} 2.3$ \\
\hline Ig03t........ & I7,475 & 3,787 & & $4,34^{\circ}$ & $9,34^{8}$ & II.5 \\
\hline $1902 \ldots \ldots \ldots$ & $\mathrm{x} 6,008$ & $\mathbf{I}, 935$ & & 5,041 & 9,032 & II. \\
\hline $901 . . . \ldots \ldots$ & I6,734 & $2,57 \mathrm{I}$ & & 5,213 & 8,950 & II. 5 \\
\hline
\end{tabular}

* Population figures used are the annual midyear estimates of the Bureau of the Census.

† Estimate based on proportion of District of Columbia unclassified cases to total unclassified cases in preceding year. No District of Columbia figures are available in the 1933 Report.

$\ddagger$ Figures for prosecutions commenced during the fiscal years I903, 1902, and I901 are not available in the Reports, but a working estimate has been obtained by subtracting the cases pending at the beginning of a fiscal year from the sum of the cases pending at the end of that year and the cases terminated during that year.

7 Cases prosecuted in the Indian Territory for violations of the Intercourse Laws arc included with the unclassified Indian Territory cases for the years 1904, 1903, 1902, 1901. After 1901 the heading "Prosecutions under Intercourse Laws" does not appear in the Reports, and the cases previously classified thereunder seem to have been placed in the unclassified column. When the Indian Ferritory was absorbed in Oklahoma, this volume of extraordinary business terminated abruptly, indicating thereby the special nature of the jurisdiction exercised. 
Generally speaking, Table I indicates an upward trend in the number of criminal prosecutions commenced each fiscal year in the District Courts of the United States, even when such deductions are made in the "net" column as are necessary to correct the distorted picture of the increase in federal crime presented in the "total" column..$^{8}$ The last column in Table I indicates that in I933 about 32.2 per cent more "net" criminal prosecutions were commenced per roo,000 population than in Igor. Comparing the I933 figure with that for I924-the first year of the last decade shown on the table-the former figure is seen to be but Ir. 8 per cent greater than the latter. The startling increase in prosecutions instituted for immigration law violations ${ }^{0}$ commencing with the fiscal year $193^{\circ}$ suffices to explain the higher rate of "net" prosecutions per roo,000 population for the last four years.

\section{Customs, Internal Revenue, Postal, Public Land Laws.}

Table 2 indicates the criminal prosecutions commenced in the United States in the fiscal years 1922 to 1933 , both inclusive, for the violation of laws relating to customs, internal revenue, the post office, and public lands. This table combines four of the principal categories found in the Annual Reports of the Attorney General, ${ }^{10}$ only one of which, "Public Lands," is subdivided there. Since violations of public land laws are relatively infrequent, no effort has been made here to follow the Attorney General's classification in this respect.

The column in Table 2 designated "Customs" covers a number of offenses which concern violations of tariff laws and related matters.

The column designated "Internal Revenue" includes criminal prosecutions for a potentially vast number of different types of offenses. Over one hundred sections of Title 26 of the United States Code concern themselves with penal provisions relating to the internal revenue laws. While no attempt will be made to indicate more specifically the nature of the laws which are covered by this column, it is well to note that criminal prosecutions commenced for violations of prohibition and liquor tax laws and the anti-narcotic acts, although long administered by the Treasury Department, ${ }^{11}$ are separately classified in the Attorney General's Report and are set forth in Table 4 below. For this reason, it seems probable that criminal prosecutions commenced to enforce the penal provisions of the regulatory tax statutes relating to oleomargarine, adulterated butter, filled cheese, mixed flour, etc. are included in the Reports under the heading "Other Food and Fuel Cases" rather than under "Internal Revenue."

${ }^{8}$ The column showing the "net" prosecutions commenced per 100,000 population may be compared with the following statement made in Sutherland and Gehlke, Crime and Punishment, 2 RECENT Social TRENDS (1933) at II30: "The federal courts' curve, from which war offenses and prohibition cases are removed, is the most interesting of all after 1920 , for it drops in three years to as low a point as it has reached since I900." The curve mentioned in this statement also affords an interesting comparison with Table $\mathrm{r}$.

- For immigration cases, see Table 7, infra.

${ }^{20}$ See note 5 , supra.

11 The enforcement of prohibition laws was shifted from the Treasury Department to the Department of Justice on June 1, 1930. 
The scope of the column designated "Postal" has been critically considered by Ploscowe, and his comment deserves mention here in order to indicate once again the difficulty of attempting to discover, by using the Reports of the Attorney General, the exact distribution among the various offenses of the criminal prosecutions which are commenced in the federal district courts. The gist of Ploscowe's criticism is "that the heading 'Postal crimes' in the court statistics of the Attorney General's Report contains many different species of criminal conduct." Such a grouping results in a failure on the part of the statistics "to provide information relating to the quantity, quality, and character of the criminality handled by the agency reporting."12

The column designated "Public Lands" includes criminal prosecutions commenced each fiscal year with respect to public lands and reservations, Indian lands, reclamation and water rights, and miscellaneous public land matters.

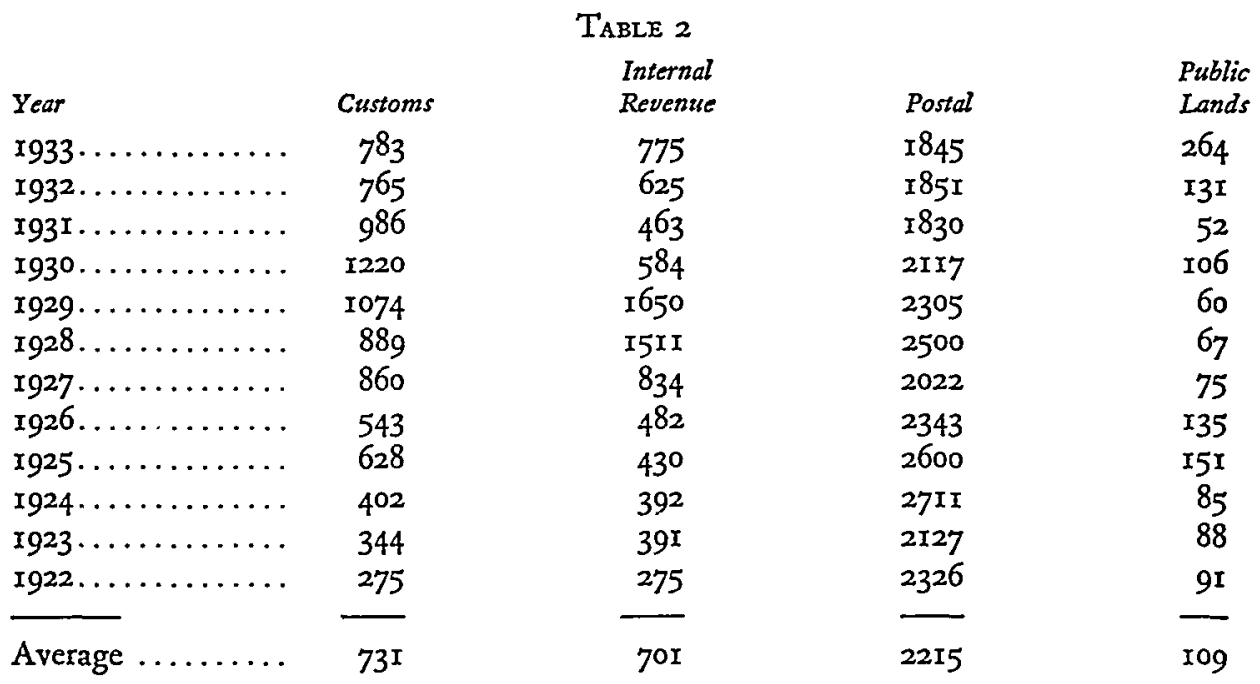

Since the four classifications appearing in this table are also to be found in the Reports from I908 to I922, some comparison with the statistics for the earlier period may be drawn. For the twelve years preceding 1922 the yearly average of criminal prosecutions commenced was as follows: (I) $43^{8}$ for customs violations, (2) 4922 for internal revenue violations, (3) I98r for postal violations, and (4) 98 for violations of public land laws.

The striking variance between the average number of criminal prosecutions commenced annually for internal revenue infractions prior to 1922 and those commenced thereafter is almost certainly due to the fact that the violations of the Harrison AntiNarcotic Act and of laws relating to liquor traffic and illicit distilling (all enforced

${ }^{13}$ See Ploscowe, op. cit. supra note 3, I73-I75. He divides the types of crime into five classes: (I) offenses the purpose of whose prohibitions is to insure the governmental monopoly over the mails, (2) offenses relating to non-mailable matters-using the mails to promote frauds, the mailing of obscene matter, etc., (3) offenses relating to interference with the expedition of mails, (4) offenses relating to violent and non-violent attacks on the mail and other post office property, counterfeiting postage stamps and money orders, larceny of mail matter, etc., (5) miscellaneous offenses. 
by the Bureau of Internal Revenue) were not separately classified in the Reports of the Attorney General for the years preceding 1922.

Turning to the period covered by Table 2, one encounters difficulties in seeking to explain the variations in the volume of criminal prosecutions for certain offenses. For example, one reads in the "Internal Revenue" column that 482 criminal prosecutions were commenced in 1926,834 in 1927 , 15 II in 1928,1650 in 1929 , and but 584 in 1930 . Why this variance? Increases in violations, greater efficiency in detection, an accumulation of cases in particular years because of administration delays or shifts in intra-departmental policy might all be factors tending to cause the yearly variations in internal revenue prosecutions. The Reports of the Commissioner of Internal Revenue shed little light on the question. It should be noted, however, that the number of income-tax cases received by the Penal Division of the Bureau shows an upward trend from 1926 to 1929 and a decline in 1930. Of course, not all of these cases reach the stage of prosecution. ${ }^{13}$

\section{Regulations of Commerce}

For convenience in presentation, Table 3 is divided into two sections, the figures for which are obtained from the statistics appearing in the various subdivisions included under the heading "Regulation of Commerce" in the Reports of the Attorney General. Criminal prosecutions involving the anti-trust laws, the orders of the Interstate Commerce Commission, violations of certain railroad regulations, ${ }^{14}$ and automobile and freight car thefts ${ }^{15}$ are totaled in Table $3^{\mathrm{A}}$. Table ${ }_{3} \mathrm{~B}$ combines the two classifications used by the Attorney General entitled "Food and Fuel" and "Miscellaneous forms of regulations." Its first column lists the criminal prosecutions commenced for the violation of the Food and Drugs Act. The other columns indicate the number of prosecutions relating to the Meat Inspection Act, and the Game Bird Acts. The column in Table $3 \mathrm{~B}$ designated "Other Cases" combines the Attorney General's headings entitled "Quarantine Acts," "Insecticide and Fungicide Acts," "Virus Acts," "Shipping Acts," and "Other Cases" (including those listed under "Food and Fuel"). Since the last mentioned group of cases, with the exception of Quarantine Act violations, results in relatively few prosecutions, segregation has not been attempted here.

${ }^{23}$ Cases involving income tax laws received by the Penal Division of the Bureau of Internal Revenuc for the years 1926 to 1930 total as follows:

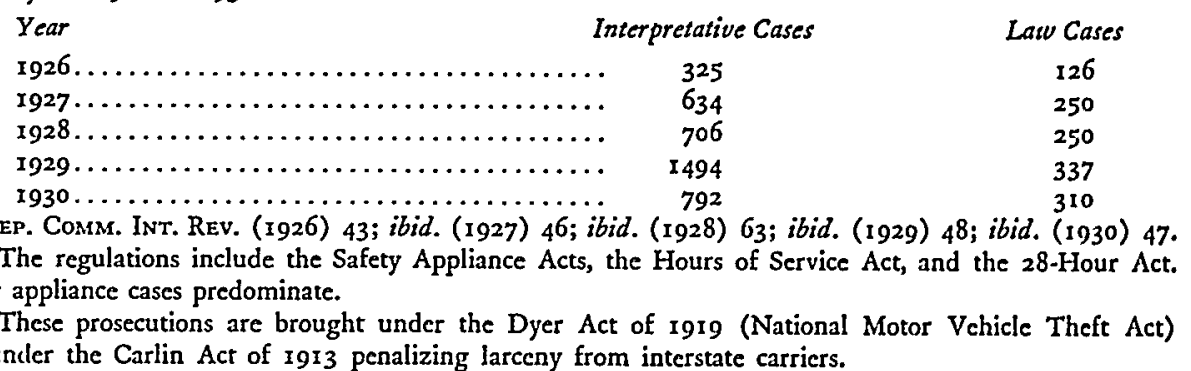
and under the Carlin Act of 1913 penalizing larceny from interstate carriers. 
TABLE 3

A.

\begin{tabular}{|c|c|c|}
\hline & & $\begin{array}{l}\text { Interstate } \\
\text { Commerce }\end{array}$ \\
\hline $1933 \ldots \ldots \ldots$ & 3 & 22 \\
\hline I932 ......... & 0 & 30 \\
\hline rg3r......... & 0 & 16 \\
\hline r930........ & I & $2 \mathrm{I}$ \\
\hline I $929 \ldots \ldots \ldots$ & 5 & 17 \\
\hline $1928 \ldots \ldots \ldots$ & 6 & $x_{3}$ \\
\hline rg27......... & 3 & I2 \\
\hline I $926 \ldots \ldots \ldots$ & 7 & to \\
\hline rg25 $\ldots \ldots \ldots \ldots$ & 5 & $\sqrt{2}$ \\
\hline $1924 \ldots \ldots \ldots$ & 3 & 43 \\
\hline Ig23......... & 16 & 18 \\
\hline I $g 22, \ldots \ldots \ldots$ & 15 & 44 \\
\hline Average & 5 & $\overline{2 T}$ \\
\hline
\end{tabular}

\begin{tabular}{|c|c|c|}
\hline $\begin{array}{c}\text { Railroad } \\
\text { Cases }\end{array}$ & Thefts & $\begin{array}{l}\text { Other } \\
\text { Cases }\end{array}$ \\
\hline 3 & $1 \sigma_{3} x$ & 64 \\
\hline 49 & I890 & 53 \\
\hline 6 & 2115 & 29 \\
\hline I & I786 & 57 \\
\hline 4 & I 772 & $3^{6}$ \\
\hline 7 & 1760 & 66 \\
\hline 42 & I 446 & 29 \\
\hline 25 & I369 & 43 \\
\hline 6 & 1035 & 52 \\
\hline 3 & 832 & 94 \\
\hline 2 & 792 & $25^{\circ}$ \\
\hline 3 & II6I & 57 \\
\hline I3 & $I_{4} 66$ & 69 \\
\hline
\end{tabular}

B.

\begin{tabular}{|c|c|c|c|c|}
\hline Year & $\begin{array}{l}\text { Food and } \\
\text { Drugs Act }\end{array}$ & $\begin{array}{c}\text { Meat } \\
\text { Inspection } \\
\text { Act }\end{array}$ & $\begin{array}{c}\text { Game Bird } \\
\text { Acts }\end{array}$ & $\begin{array}{l}\text { Other } \\
\text { Cases }\end{array}$ \\
\hline r $933 \ldots \ldots \ldots \ldots \ldots$ & 368 & 29 & 371 & $\mathrm{I} 29$ \\
\hline 1932 $\ldots \ldots \ldots \ldots \ldots \ldots$ & 296 & $r_{4}$ & 305 & I76 \\
\hline 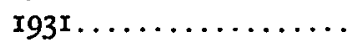 & 85 & $3 I$ & 386 & 207 \\
\hline x $93^{\circ} \ldots \ldots \ldots \ldots \ldots \ldots$ & 60 & 37 & 370 & 240 \\
\hline 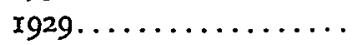 & 70 & 24 & 402 & 167 \\
\hline 1928 $\ldots \ldots \ldots \ldots \ldots \ldots$ & 84 & 52 & 376 & 220 \\
\hline I927 $\ldots \ldots \ldots \ldots \ldots \ldots$ & $\mathrm{I} 22$ & 22 & 428 & rgr \\
\hline 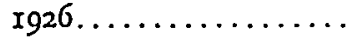 & I63 & 19 & 502 & 278 \\
\hline rg25 $\ldots \ldots \ldots \ldots \ldots$ & 959 & 33 & $6_{35}$ & 270 \\
\hline$x 924 \ldots \ldots \ldots \ldots \ldots$ & 357 & 37 & $6 r x$ & $3^{17}$ \\
\hline $1923 \ldots \ldots \ldots \ldots \ldots$ & 234 & 48 & $45^{6}$ & 339 \\
\hline r $922 \ldots \ldots \ldots \ldots \ldots \ldots$ & 378 & 39 & 6II & 449 \\
\hline Average.......... & 265 & 32 & 454 & 249 \\
\hline
\end{tabular}

Prior to I922 the only column headings in the Attorney General's Reports similar to those employed in Table $3 \mathrm{~A}$ were "Anti-Trust" and "Interstate Commerce Laws." 16 An average of ten criminal prosecutions per year were commenced during the years IgIO-I92I for violations of the anti-trust laws, whereas the yearly average for I922-23 was slightly more than five. Trust-busting apparently grew less popular in the late New Era. A summary of the criminal prosecutions listed under "Interstate Commerce Laws" in the Reports prior to rg22 shows the following:

${ }^{18}$ See note 5, supra. 

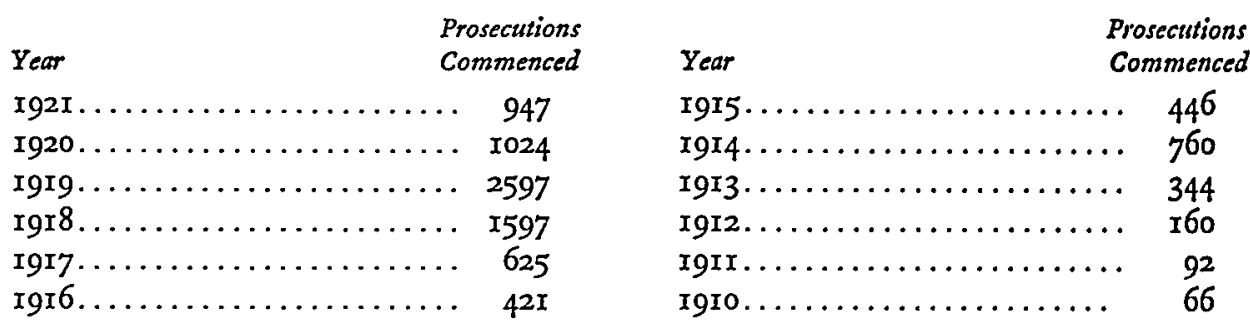

It seems likely that the upswing in prosecutions commenced during the years I9I8-I92I is due to the fact that this category included prosecutions instituted for violations of the I9I7 Reed Act prohibiting shipment of liquor into dry states. In addition, the I 920 and I92I data undoubtedly include figures for the National Motor Vehicle Theft Act prosecutions. The ${ }_{4} \mathrm{r} 6$ additional criminal prosecutions commenced in IgI4 as compared to the preceding year is probably due to the passage in Igr3 of the Carlin Act relating to larceny from interstate carriers.

\section{Public Health and Safety.}

Although certain of the criminal prosecutions totaled in the table below have interference with interstate commerce as their constitutional bases, the Attorney General's Reports place such infractions under the heading "Public Health and Safety." In Table 4, the content of the column designated "Prohibition" is the same as the similar column in Table r. "Other Liquor Traffic Cases" probably refers for the most part to prosecutions or indictments brought under internal revenue laws relating to liquor traffic. ${ }^{17}$ The importation and exportation of narcotic drugs are regulated by the Narcotic Drugs Import and Export Act of Ig0g. The domestic sale or dispensing of narcotics is governed by the Harrison Anti-Narcotic Act of 19r4. The White Slave Traffic Act, popularly known as the Mann Act, passed in x9I0, punishes offenses relating to the transportation of women or girls in interstate or foreign commerce for immoral purposes. In the column designated "Other Cases" there have been included the few criminal prosecutions commenced for the violation of peonage laws, separately classified in the Attorney General's Reports.

TABLE 4

$\begin{array}{lccccc}\text { Year } & \text { Prohibition } & \begin{array}{c}\text { Other Liquor } \\ \text { Traffic Cases }\end{array} & \begin{array}{c}\text { Anti-Narcotic } \\ \text { Acts }\end{array} & \begin{array}{c}\text { White Slave } \\ \text { Act }\end{array} & \begin{array}{c}\text { Other } \\ \text { Cases }\end{array} \\ \text { I933 } \ldots \ldots \ldots \ldots & 57,553 & \text { I061 } & 2305 & 323 & 537 \\ 1932 \ldots \ldots \ldots \ldots & 65,960 & 1433 & 2496 & 375 & 453 \\ 1931 \ldots \ldots \ldots \ldots & 57,405 & 1345 & 2674 & 467 & 546\end{array}$

${ }^{17}$ After the passage of the Volstead Act, the Supreme Court in U. S. v. Yuginovich, 256 U. S. 450, 4I Sup. Ct. 55I (I92I), held that a number of sections of the internal revenue laws had been repealed by the Volstead Act. Congress thereupon passed a supplemental act (Willis-Campbell Act, \$5, 42 STAT, 222 (I92I), 27 U. S. C. A. \$3) continuing in effect or reënacting all revenue laws regarding intoxicating liquors and existing prior to the Volstead Act, except those in direct conflict with the latter. Thereafter "the Internal Revenue Act and the Liquor Act have been in force concurrently, despite the fact that they contain different penalties, and the government agencies, at their option or election, have procecded first under one and then the other, both as to prosecution and as to matters of forfeiture." U. S. v. Bacon, 7 F. Supp. 590, 59x (W. D. Tex. 1934). 


\begin{tabular}{|c|c|c|c|c|c|}
\hline $1930 \ldots \ldots \ldots$ & $5^{6,992}$ & $I_{4} 88$ & 3505 & 532 & 443 \\
\hline$x 929 \ldots \ldots \ldots \ldots$ & 56,786 & 1593 & 3909 & 529 & $44^{8}$ \\
\hline 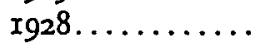 & 55,729 & 1307 & 3798 & 554 & 460 \\
\hline 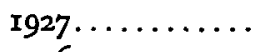 & 40,709 & 903 & 3295 & 557 & 401 \\
\hline I926.......... & 44,492 & 879 & 4120 & $60 r$ & 3 \\
\hline I $925 \ldots \ldots \ldots \ldots$ & $5^{0}, 743$ & 945 & 5268 & 630 & 54 \\
\hline I924 $\ldots \ldots \ldots \ldots$ & 45,878 & 553 & 4273 & 634 & 5 \\
\hline $1923 \ldots \ldots \ldots \ldots$ & $49,02 I$ & 499 & 4393 & $4^{69}$ & 369 \\
\hline $1922 \ldots \ldots \ldots \ldots$ & 34,984 & $35^{6}$ & 4221 & 528 & $3^{8}$ \\
\hline verage..... & & xo3o & $3^{688}$ & 7 & \\
\hline
\end{tabular}

Table 4 indicates that in the depression years 1930 -1933, prosecutions under the Anti-Narcotic Acts declined 4I per cent, and those under the White Slave Act, 38.9 per cent, from the rg2g totals. However, the "Prohibition" column indicates that the high costs of iniquity hampered neither bootleggers nor their patrons during the depression. The Attorney General in his 1932 Report makes no endeavor to explain the increase of 8,555 prohibition cases in 1932 over 193I. While the 1932 Report of the Director of Prohibition does not supply this explanation, his 1933 Report traces the decrease in cases during 1933 as compared with 1932 to "legislative changes in procedure"18 and the legalizing of beer on March 22, 1933. The year 1925 found a sharp increase in prosecutions commenced for narcotic violations. A clue to the cause of this increase may be found in the fact that an average of 305 agents and inspectors served in the narcotic field force in 1925 as compared to 176 in $1924 .{ }^{19}$

\section{Banking and Finance.}

Table 5 concerns itself with the criminal prosecutions commenced for violations of the National Banking Laws, Federal Reserve Act, Federal Farm Loan Act, and Bankruptcy Acts. To indicate more specifically the nature of the offenses occurring under these categories is a difficult task, since the infractions cover a wide variety of acts such as forgery, lending trust funds to officers, embezzlement, making false statements knowingly for the purpose of influencing the action of a Federal Reserve bank on discounts, loans, and extensions, embezzling property belonging to a bankrupt estate, knowingly and fraudulently making a false oath in a bankruptcy proceeding, etc. Cases which the Attorney General classifies under the heading "War Finance Corporation" are combined with the "Other Cases" column.

\footnotetext{
${ }^{28}$ These changes refer to the prohibition of the use of funds for wire-tapping and for the purchase of intoxicating liquors by investigators. Sie Rep. Arr'y Gen. (1933) 40, 4I.

${ }^{19}$ See Rer. Comm. INT. Rev. (I924) 33-35; ibid. (I925) 30-32.
} 
TABLE 5

\begin{tabular}{|c|c|c|c|c|c|}
\hline Nati & $\begin{array}{l}\text { nal Banking } \\
\text { Laws }\end{array}$ & $\begin{array}{c}\text { Federal Reserve } \\
\text { Act }\end{array}$ & $\begin{array}{c}\text { Federal Farm } \\
\text { Loan Act }\end{array}$ & $\begin{array}{c}\text { Bankruptcy } \\
\text { Acts }\end{array}$ & $\begin{array}{l}\text { Other } \\
\text { Cases }\end{array}$ \\
\hline I933........ & $3 r 7$ & 28 & 29 & $r_{5} 6$ & $5 \times 7$ \\
\hline $1932 \ldots \ldots \ldots$ & 305 & $5^{8}$ & 82 & xI5 & $37 x$ \\
\hline 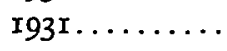 & 427 & 34 & 14 & $17^{8}$ & 242 \\
\hline x930.......... & 216 & 26 & 13 & I80 & $24 I$ \\
\hline I929......... & 280 & I6 & 14 & $13^{6}$ & 175 \\
\hline r928. . & 303 & $4 I$ & 4 & $15^{8}$ & 168 \\
\hline rg27......... & 184 & $2 r$ & 5 & 102 & $x_{43}$ \\
\hline r $926 \ldots \ldots \ldots$ & rg2 & I4 & 5 & - & $x 43$ \\
\hline rg25......... & 236 & 27 & 4 & - & 148 \\
\hline r $924 \ldots \ldots \ldots$ & 283 & 30 & 5 & 一 & 183 \\
\hline $1923 \ldots \ldots \ldots$ & $26 \mathrm{I}$ & 18 & 3 & - & 210 \\
\hline rg22......... & 200 & 42 & 9 & 一 & $x 89$ \\
\hline verage. & $\overline{267}$ & $\overline{30}$ & $\overline{16}$ & $\overline{146}$ & 227 \\
\hline
\end{tabular}

When the figures in the "National Banking Laws" column in Table 5 are compared with the data in the Banking Acts column of the Attorney General's Reports prior to I922, one discovers that an average of about 180 more criminal prosecutions per year were commenced during the years $1922-1933$ than during the period from I910-rg2I. The textual material of the Reports of the Attorney General acknowledges this increase but gives no explanation. Probably this is due to an increase in violations rather than to the enactment of new laws or to a change in classification. ${ }^{20}$

\section{Liability and Insurance.}

Table 6 lists the criminal prosecutions commenced for offenses connected with the War Risk Insurance and Pension Acts. The few criminal prosecutions arising under the federal employees' compensation statutes"1 are combined with "Other Cases" to form the third column.

TABLE 6

\begin{tabular}{|c|c|c|c|}
\hline Year & Insurance & Pension Acts & Other Cases \\
\hline r $933 \ldots \ldots \ldots \ldots \ldots \ldots \ldots \ldots \ldots$ & 77 & 8 & 37 \\
\hline 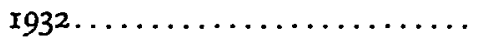 & 87 & 5 & 18 \\
\hline I93 I $\ldots \ldots \ldots \ldots \ldots \ldots \ldots \ldots$ & 62 & 2 & 33 \\
\hline 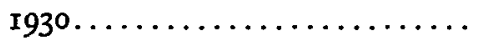 & 83 & 6 & 30 \\
\hline 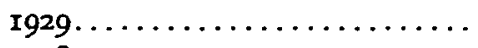 & 77 & 8 & I5 \\
\hline 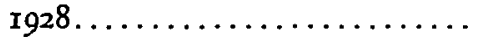 & 66 & 2 & 34 \\
\hline 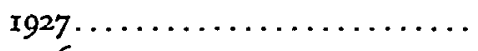 & 46 & 4 & $3^{8}$ \\
\hline 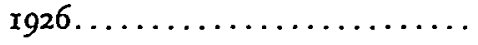 & 39 & 4 & 4 \\
\hline
\end{tabular}

${ }^{20}$ In addition, it is well to note that counterfeiting cases, segregated in the Attorney General's Reports during the years $191 \mathrm{I}-192 \mathrm{r}$, were prosecuted at an average rate of 250 cases per year during that period. It is difficult to surmise whether these cases have been included in the miscellaneous case totals of the Attorney General's Reports for the years 1922-1933 or whether they have been distributed to some extent in the columns of Table 5 .

${ }^{21}$ The statutes include the Longshoremen's and Harbor Workers' Compensation Act of r927, the District of Columbia Employes' Compensation Act of 1928, and the Employes' Compensation Act of 1908. 


\begin{tabular}{|c|c|c|c|}
\hline 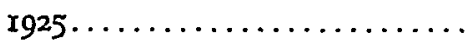 & $4 I$ & 7 & 7 \\
\hline I $924 \ldots \ldots \ldots \ldots \ldots \ldots \ldots \ldots$ & 65 & 5 & II \\
\hline 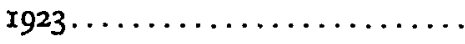 & 57 & 4 & 7 \\
\hline I $922 \ldots \ldots \ldots \ldots \ldots \ldots \ldots \ldots$ & 99 & II & I \\
\hline$=$ & - & - & 一 \\
\hline Average & 67 & 5 & 20 \\
\hline
\end{tabular}

The figures in Table 6 are of small moment as far as federal criminal activity is concerned. One interesting comparison, however, is afforded by contrasting them with the figures available for the years I902-I908, showing the number of criminal prosecutions commenced annually under the pension laws. These cases, involving Spanish-American and Civil War pension provisions, averaged $\mathrm{x} 60$ annually as compared with the average of 67 prosecutions per year under the War Risk Insurance Act.

\section{Foreign Relations.}

Table 7 indicates the criminal prosecutions commenced for offenses relating to immigration laws, naturalization laws, and admiralty. A departure is made from the classification in the Reports of the Attorney General in that the columns designated by the Attorney General as "Trading with Enemy," "Alien Property," and "War Trade and Industries" are included as part of the war case column of Table $\mathrm{I}$. Infractions covered by the immigration column of Table 7 include such acts as the reëntry of excluded aliens, importation of aliens for immoral purposes, forging, altering, or falsely making any immigration visa or permit, offenses connected with the coolie trade, etc. The admiralty column of Table $\eta$ lists the criminal prosecutions commenced for such acts as murder, manslaughter, rape, etc., when committed on the high seas, on waters within the admiralty jurisdiction of the United States, etc. Criminal prosecutions for violations of navigation laws and harbor regulations tried as in admiralty are also listed in the admiralty column.

TABLE 7

\begin{tabular}{|c|c|c|c|c|}
\hline Year & Immigration & Naturalization & Admiralty & $\begin{array}{l}\text { Other } \\
\text { Cases }\end{array}$ \\
\hline I933 $\ldots \ldots \ldots \ldots \ldots$ & 4395 & I08 & 2 & ro \\
\hline I932............. & $594 j$ & $15^{8}$ & 7 & $\mathbf{o}$ \\
\hline I93I ............. & 6293 & I32 & 3 & I8 \\
\hline I930............. & 7001 & 62 & II & 4 \\
\hline 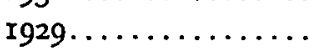 & 1568 & 56 & 0 & 13 \\
\hline 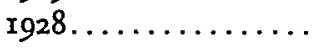 & $57^{\circ}$ & 36 & I & $x 6$ \\
\hline I927 $\ldots \ldots \ldots \ldots \ldots$ & $68 x$ & I9 & $\mathbf{I}$ & 9 \\
\hline 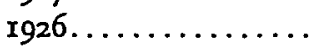 & 771 & 89 & 3 & 95 \\
\hline $1925 \ldots \ldots \ldots \ldots \ldots$ & 1467 & 39 & 7 & 16 \\
\hline $1924 \ldots \ldots \ldots \ldots \ldots$ & 482 & 74 & 12 & $x_{4}$ \\
\hline $1923 \ldots \ldots \ldots \ldots \ldots$ & 256 & 35 & $I$ & 6 \\
\hline $1922 \ldots \ldots \ldots \ldots \ldots$ & $2 \times 9$ & $3^{8}$ & 3 & $4^{2}$ \\
\hline$\overline{\text { Average }} . . . . \ldots \ldots$ & $\overline{2470}$ & $\overline{70}$ & - & $\overline{20}$ \\
\hline
\end{tabular}


The $\mathrm{x}, 568$ criminal prosecutions commenced in 1929 for violations of the immigration laws constituted 1.8 per cent of all criminal actions brought in the district courts for that year and 8.6 per cent of the net criminal prosecutions commenced. In 1930, the number leaped to 7,00I, 8 per cent of all criminal actions brought in the district courts and 3I.3 per cent of the net prosecutions instituted. "This increase is the result of the operation of the Act of March 4, 1929, making it a penal offense for an alien to enter the United States after having been deported, or to enter without inspection or by wilfully false or misleading statements. Prior to such act, it was possible, generally speaking, to deport only aliens who smuggled themselves into the United States."22 The Attorney General's Report gives no explanation for the increase in $r 929$ over 1928 , but the increase in 1925 as compared to 1924 is attributed "to attempts to evade the provisions of the immigration act of $\mathrm{x} 924$, which very materially reduced the number of aliens admissible each year as compared with the number admissible under prior laws."23

\section{Cases Not Specially Classified.}

Despite the extension in 1922 of the classification scheme of the Attorney General's Reports, prosecutions are still commenced each year for a vast number of offenses not specially classified, occurring to a great extent in the District of Columbia where the major portion of the Supreme and Police Courts' business approaches that of a typical state criminal court.

The Reports of the Attorney General divide the not specially classified cases into three parts: ( $x$ ) Selective Service, (2) Indian matters other than those relating to Indian lands, (3) Other cases. Table 8 departs from this classification and has two categories: (I) Total cases not specially classified in Tables 2-7, (2) District of Columbia cases not specially classified in Tables 2-7. The selective service cases are included in the "War Cases" column of Table $\mathrm{I}$, Indian matters are included in the "Total" column of Table $I$, and the Indian land cases are included in the "Public Land" column of Table 2. To indicate further the nature of the varied mass of cases included in Table 8 would be impossible.

TABle 8

\begin{tabular}{|c|c|c|c|c|}
\hline Year & $\begin{array}{l}\text { Total Cases Not } \\
\text { Specially Classified }\end{array}$ & $\begin{array}{c}\text { Dist. of } \\
\text { Columbia Cases } \\
\text { Not Specially } \\
\text { Classified }\end{array}$ & $\begin{array}{cc}\text { Total Cases Not } \\
\text { Year Specially Classified }\end{array}$ & $\begin{array}{c}\text { Dist. of } \\
\text { Coltumbia Cases } \\
\text { Not Specially } \\
\text { Classified }\end{array}$ \\
\hline I933. & $\ldots \quad 8,923$ & 5,971 & $1927 \ldots$ rr,409 & 9,694 \\
\hline I932. & 8,123 & 5,772 & I926... I0,82I & 8,682 \\
\hline I93r. & $\ldots \quad 7,666$ & 5,576 & r $925 \ldots .9,167$ & 7,157 \\
\hline I930. & $\ldots 9,870$ & 7,957 & $1924 \ldots \ldots$ II,260 & 8,935 \\
\hline I929. & $\ldots \quad 13,139$ & II,544 & $1923 \ldots \quad 10,35^{8}$ & 7,674 \\
\hline r 928. & $\ldots \quad 12,574$ & 10,706 & I922... I0,370 & 8,149 \\
\hline
\end{tabular}


When regard is had for the number of unclassified cases which are tried in the District of Columbia courts, the cases not specially classified by the Attorney General do not bulk large in relation to either total or net criminal prosecutions. ${ }^{24}$ The adoption of the 1922 classification led to a marked reduction in the number of unclassified cases not attributable to prosecutions in the District of Columbia.

\section{Percentage of Prosecutions Terminating in Convictions.}

In order to indicate the success of the federal government in procuring convictions in the criminal cases commenced, and in order to present a further measure of the amount of federal criminal activity, Table 9 shows the percentage of prosecutions in the federal district courts which terminate in convictions. Not only are the yearly percentages of the total cases ending in convictions listed, but similar data are included for prohibition, immigration, and theft cases. These three classes of cases are numerically significant, and each represents a different type of enforcement problem.

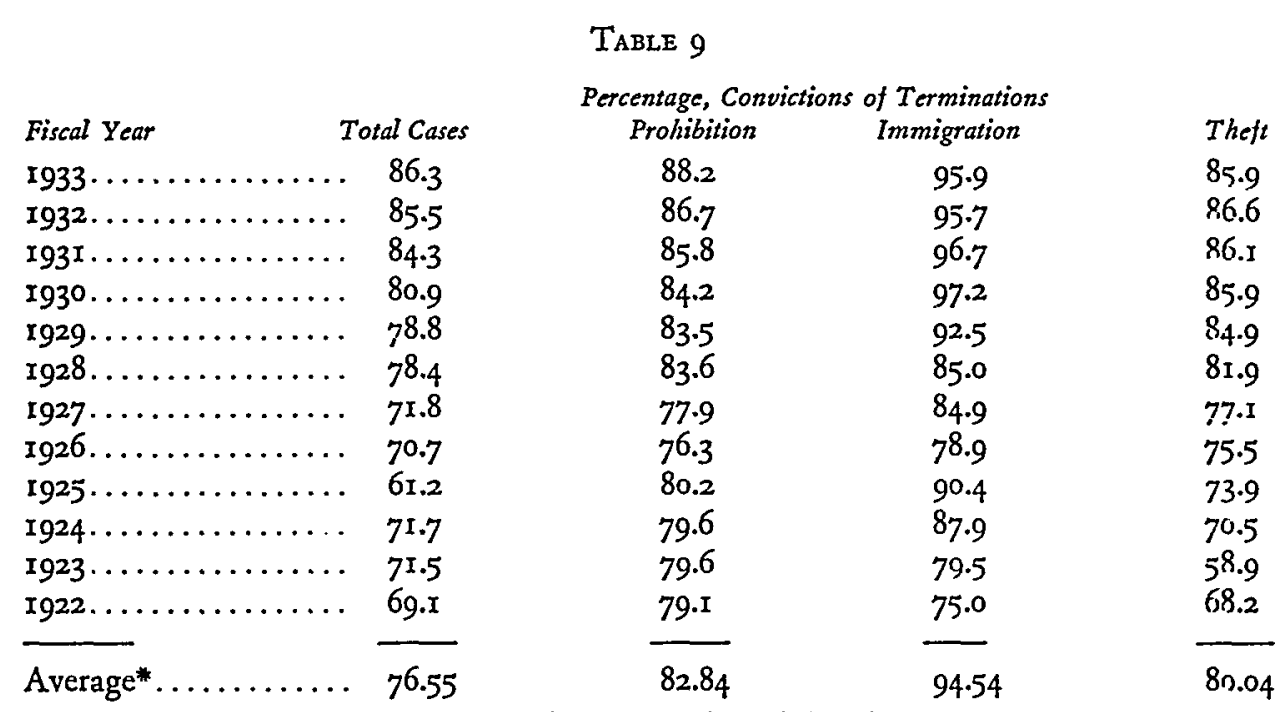

- Obtained by dividing the average yearly number of convictions by the average yearly number of terminations.

The percentage of cases terminating in convictions has been growing larger since 1922. Of course, exceptions in given years are to be expected. The low I925 figure in the "Total" column is explained by the statistics relating to war case convictions in that year. Of the 23,735 selective service cases pending in 1925 , I8,47I were ter-

\footnotetext{
24 Ploscowe overemphasizes the incompleteness of the Attorney General's present classification by ignoring the fact that the majority of not specially classified cases are District of Columbia cases which would be both difficult and inappropriate to classify in a report pertaining to crimes of a federal character. See Ploscowe, op. cit. supra note $3,175,176$.
} 
minated, and but 4 convictions resulted.25 Virtually all were noll-prossed. This situation was, of course, extraordinary, but even in normal years a substantial proportion of prosecutions not terminating in convictions do not result in acquittals. Thus, in the past three years, noll-prosses, discontinuances, and the quashing or dismissal of cases have outnumbered acquittals in the disposition of federal prosecutions. ${ }^{28}$

\section{General Conclusions}

The collation of statistics relating to federal criminal prosecutions and the brief discussion of the scope and meaning of the various tables permit at least three conclusions: ( $\mathrm{r}$ ) Although improvement has been made in the classification used in the Attorney General's Reports, there is still a paucity of refined data respecting federal criminal activity, which makes any interpretation of the criminal business before the federal courts a hazardous task. Whether or not an entirely different method of classification should be employed will not be considered here. ${ }^{27}$ Were a new method adopted, it might still be advisable to continue the present classification in order to permit comparisons in the future with the years 1922-1933. With the recent enactment of important new laws relating to federal crime, it may become necessary, however, to include additional columns in the Attorney General's Reports. In any event, a more detailed explanation of the scope of the column headings employed by the Attorney General would enhance their value. (2) The trend of federal crime has been upward, but when war cases, prohibition cases, etc., are deducted from the total criminal prosecutions each year, the number of net criminal prosecutions commenced per 100,000 population has not varied to any great extent from year to year during the last decade. (3) When federal criminal activity is considered with respect to separate classes of offenses, the trend is neither uniform nor always upward, but whether such variations are due to change in the classificatory scheme of the Reports, to statutory changes, to more or less stringent enforcement, or to a greater or fewer number of violations of given laws is difficult to ascertain from available data.

s5 REP. ATt'y Gen. (I9I5) 8r. The following table indicates the volume and disposal of war cases for the years 1918 -rg25.

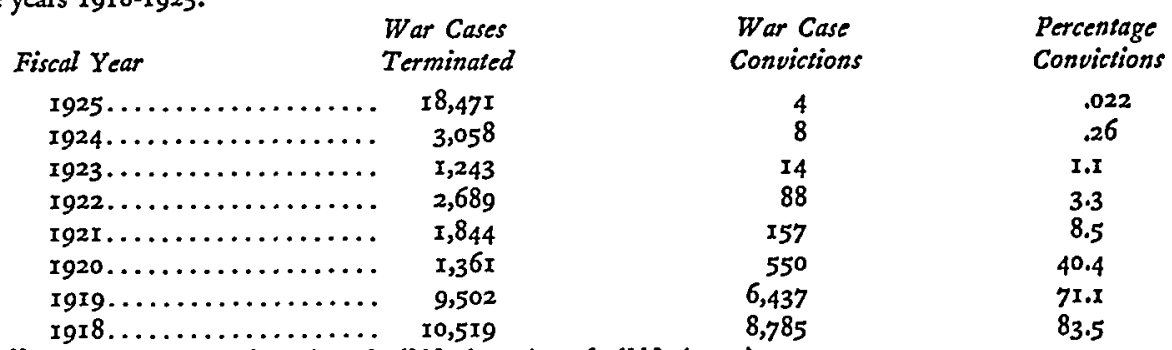

${ }^{2}$ Rep. Atr'y Gen. (1933) r38; ibid. (r932) r46; ibid. (r93I) r40.

${ }^{2}$ See Ploscowe, op. cit, supra note 3, 170 et seq., for a general discussion of the value of the present federal court statistics. 